ARTICLE

\title{
Antarctic Peninsula warm winters influenced by Tasman Sea temperatures
}

Kazutoshi Sato ${ }^{1,2 \times}$, Jun Inoue $3,4,2$, lan Simmonds (10 ${ }^{5}$ \& Irina Rudeva (i) 6,5

The Antarctic Peninsula of West Antarctica was one of the most rapidly warming regions on the Earth during the second half of the 20th century. Changes in the atmospheric circulation associated with remote tropical climate variabilities have been considered as leading drivers of the change in surface conditions in the region. However, the impacts of climate variabilities over the mid-latitudes of the Southern Hemisphere on this Antarctic warming have yet to be quantified. Here, through observation analysis and model experiments, we reveal that increases in winter sea surface temperature (SST) in the Tasman Sea modify Southern Ocean storm tracks. This, in turn, induces warming over the Antarctic Peninsula via planetary waves triggered in the Tasman Sea. We show that atmospheric response to SST warming over the Tasman Sea, even in the absence of anomalous tropical SST forcing, deepens the Amundsen Sea Low, leading to warm advection over the Antarctic Peninsula.

\footnotetext{
${ }^{1}$ Kitami Institute of Technology, Kitami, Japan. ${ }^{2}$ Application Laboratory, Japan Agency for Marine-Earth Science and Technology, Yokohama, Japan. ${ }^{3}$ National Institute of Polar Research, Tachikawa, Japan. ${ }^{4}$ The Graduate University for Advanced Studies, SOKENDAI, Hayama, Japan. ${ }^{5}$ School of Earth Sciences, The University of Melbourne, Melbourne, Australia. ${ }^{6}$ Australian Bureau of Meteorology, Melbourne, Australia. ${ }^{凶}$ email: satokazu@mail.kitami-it.ac.jp
} 
T he West Antarctic region, and the Antarctic Peninsula (AP) in particular, experienced dramatic temperature changes from the International Geophysical Year 1958 to the late 20th century. Significant long-period warming of the troposphere has been revealed in observations (e.g., from surface stations $^{1-3}$, radiosondes ${ }^{4,5}$, and satellites ${ }^{6,7}$ ) and reanalysis data ${ }^{8,9}$ in all seasons, with the highest warming rate in winter. Although positive trends in surface air temperature were found in the entire $\mathrm{AP}$, the warming rate has been particularly marked at stations on the west side of the $\mathrm{AP}^{2,8}$. The $\mathrm{AP}$ air temperature trends are sensitive to the chosen start and end years of periods and period length ${ }^{3,7,10,11}$. There has been a statistically significant warming trend over the AP for a long period ${ }^{1,3,4,6,7,9-11}$. In contrast, for short periods, warming trends over the AP are not seen during austral summer, essentially because of natural internal variability ${ }^{3,10,11}$.

The increases in air temperature over Antarctica are related to enhanced warm advection associated with changes in the key atmospheric circulations over the Southern Ocean (SO) (e.g., the Amundsen Sea Low $[\mathrm{ASL}]^{12-16}$ and the Southern Annular Mode $\left.[S A M]^{17-21}\right)$. The ASL, the sea level pressure (SLP) structure of which is related to the number and intensity of low-pressure systems over the Amundsen Sea, plays an important role in the West Antarctic surface climate (e.g., surface air temperature, sea ice extent, and wind speed), particularly during winter when cyclones are more numerous and deeper ${ }^{14-16}$. The SAM, characterized by westerly circumpolar flow variability associated with the strong meridional pressure gradient between the high and mid-latitudes of the Southern Hemisphere (SH), greatly influences synoptic-scale activity over the SO. A positive SAM causes poleward displacement of the cyclone tracks and reinforces the ASL, promoting surface warming over the $\mathrm{AP}^{16,20,21}$.

The relationships between the atmospheric circulation over the SO and tropical oceanic variability, often called 'tropical-polar teleconnections', have been examined in previous studies $8,9,16,22-41$. In the austral cold seasons, heating by anomalous sea surface temperatures (SSTs) in the tropical region generates a Rossby wave train from the tropics to the Antarctic region via the SO, influencing its teleconections ${ }^{8,9,22-24}$. By this mechanism, the El Niño-Southern Oscillation (ENSO) modulates the position and strength of the ASL $16,22,23,25,26$. Numerical experiments have shown that warming over the tropical Atlantic and Indian Oceans and cooling over the tropical eastern Pacific Ocean result in a deeper ASL and West Antarctic warming ${ }^{23}$. In addition, the longitudinal Indian Ocean SST contrast, known as the Indian Ocean Dipole (IOD), has a remote effect on the climate over the $\mathrm{SH}^{40,41}$. When the eastern Indian Ocean has a cold SST anomaly compared with the western Indian Ocean (positive phase of the IOD) without ENSO, the pressure anomaly is negative (positive) north (south) of the Ross Sea (Australia), promoting sea ice formation west of the Ross Sea ${ }^{41}$. However, a recent study has revealed considerable uncertainties in both the pattern and amplitude of the atmospheric response to ENSO due to interannual variability in the extratropics ${ }^{42}$. Various studies have reported strong Northern Hemisphere high-latitude atmospheric responses to atmospheric and oceanic forcing over the northern mid-latitudes ${ }^{43-48}$. However, no previous study has reported the impact of change in SSTs in the SH mid-latitudes on Antarctic climate variability.

In this study, we investigate the linkage between ocean variabilities in the Southern Hemisphere mid-latitudes and Antarctic warming using reanalysis datasets and an atmospheric general circulation model. We reveal that warming in the Tasman Sea strengthens the meridional SST gradient between mid-latitude and high-latitude in the Southern Hemisphere, promoting AP warming through the poleward shift of storm tracks over the SO. In addition, our model experiments show that the increase in SST in the Tasman Sea alone produces warming in the AP even without anomalous tropical SST cooling.

\section{Results}

Warm and cold winters at six stations on the Antarctic Peninsula. To understand the connection between interannual variability of SSTs in the mid-latitudes and changes in AP air temperature, we evaluated a time series of averaged surface air temperature anomalies for winter (June to August) and the other three seasons over the period 1979-2019 at six stations in the AP (Fig. 1a, see "Methods" section). The data exhibited an interannual half standard deviation $(0.5 \sigma)$ of $1.0^{\circ} \mathrm{C}$. The averaged temperatures anomalies in thirteen years exceeded $+0.5 \sigma$ ('warm' AP winters), whereas twelve winters recorded mean temperatures less than $-0.5 \sigma$ ('cold' AP winters). Although weak negative trends of AP air temperature since 1999 were reported by a previous study ${ }^{10}$, our analysis shows that the AP stations experienced eight warm winters since that time (in 2000, 2004, $2008,2010,2014,2016,2018$, and 2019). To investigate the causes of the temperature differences, we constructed difference maps of atmospheric and oceanic fields between composites of warm and cold AP winters using the Climate Forecast System Reanalysis (CFSR) provided by the National Centers for Environmental Prediction ${ }^{49,50}$ (see "Methods" section), which have relatively small biases in atmospheric parameters ${ }^{51}$. A negative sea ice concentration anomaly is seen near the AP, suggesting that this sea ice loss contributed to and/or resulted from the warm temperature (Fig. 1b). However, an east-west seesaw pattern of high and low sea ice concentration anomalies was observed between the Amundsen Sea and the area near the AP, resulting from sea ice drifting speed anomalies near the AP and over the Amundsen Sea. Therefore, surface conditions (e.g., air temperature and sea

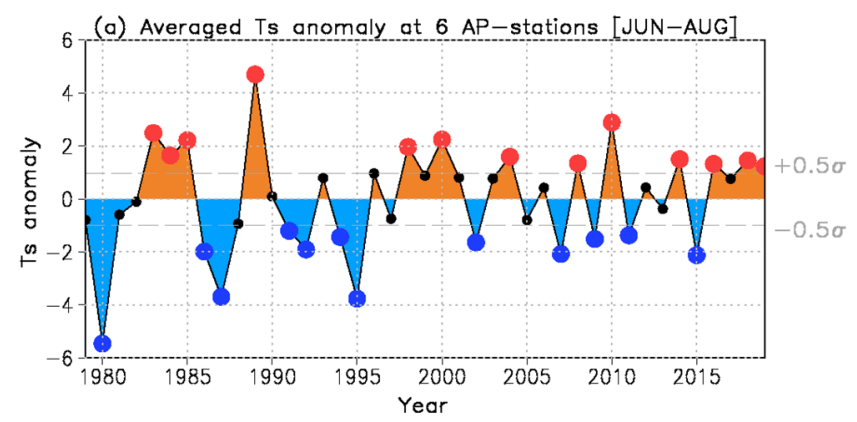

(b) IC \& ID differences (Warm - Cold)

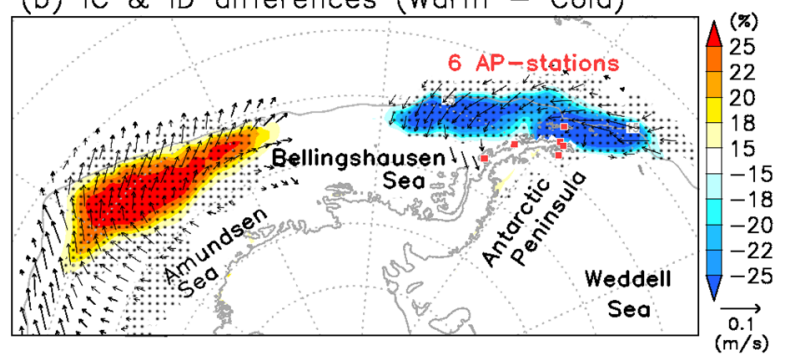

Fig. 1 Surface anomalies of West Antarctica. a Time series of averaged surface air temperature anomalies $\left({ }^{\circ} \mathrm{C}\right.$, deviation from climatology for 1979-2019) during June to August at six Antarctic Peninsula stations (Bellingshausen, O'Higgins, Esperanza, Marambio, Vernadsky and Rothera). Red and blue dots indicate the top thirteen warm winters and twelve cold winters. Dashed lines show one-half standard deviation $( \pm 0.5 \sigma)$. b Difference map of sea ice concentration (IC) (\%: shaded) and ice drifting speed (ID) ( $\mathrm{m} / \mathrm{s}$ : vector) between warm and cold winters. Dotted areas denote significant differences exceeding the $95 \%$ confidence level. 
ice concentration) in these regions would be induced by atmospheric circulation anomalies over the SO.

\begin{abstract}
Atmospheric circulation and Antarctic Peninsula warming. Figure $2 \mathrm{a}$ shows the differences in temperature at $700 \mathrm{hPa}$ (T700) and SLP between warm and cold AP winters. There is a cyclonic anomaly over the Amundsen Sea and an anti-cyclonic anomaly off the east coast of Argentina. This pattern resulted in a strong SLP gradient over the Drake Passage, leading to northerly warm advection over the Weddell Sea and the AP. The poleward drifting of sea ice associated with the northerly wind anomaly decreased sea ice extents over the Bellingshausen Sea and Drake Passage (Fig. 1b). The strong Amundsen Sea cyclonic anomaly, which has also been referred to as the ASL in some studies ${ }^{12,14,15,18}$, enhanced warm advection over the AP. In contrast, the southerly cold advection from Antarctica induced cold temperature anomalies and an equatorward shift of sea ice over the Ross and Amundsen Seas.
\end{abstract}

The $300 \mathrm{hPa}$ geopotential height (Z300) anomalies show a strong wave-like structure excited over the SO (Fig. 2b), resembling a zonal wave 3 pattern ${ }^{52}$. This pattern is similar to atmospheric responses to tropical SST anomalies reported by previous studies (e.g., tropical-polar teleconnections $8,9,16,22-41$ ), although the strongest wave anomaly pattern appears over the mid-latitudes and high latitudes. The propagation of wave activity flux as indicated by arrows ${ }^{53}$ shows a wave train originating from the south of the New Zealand region. This suggests that these wave-like anomaly patterns are associated with the variability of the mid-latitudes, particularly changes in SST in the Tasman Sea because there was a positive relationship between SST in the Tasman Sea and T700 over the AP (Supplementary Fig. 1).

To address the causes of SLP anomalies over the SO and Antarctica, we show composite maps of the densities of cyclones in warm and cold AP winters (see "Methods" section). An area of high cyclone density was found around the Antarctic coastline in both composites (Supplementary Fig. 2). These patterns are consistent with the results of previous studies ${ }^{12-15,18,21}$. However, there were positive differences in the density of cyclones over the Antarctic coastal regions, particularly in the Pacific sector (Fig. 2c). In contrast, negative differences were seen over the Drake Passage and in the central Pacific to the east of New Zealand. In addition, positive precipitation anomalies over the south-eastern Pacific and negative anomalies to the east of Argentina and New Zealand are consistent with the geographical distribution of changes in cyclone density (Fig. 2c, d). These patterns suggest that the cyclones tended to shift poleward in warm AP winters.

Impact of Tasman Sea warming on the atmospheric circulation over the Southern Ocean. In recent years, considerable warming has occurred in the Tasman Sea ${ }^{54}$, and the frequency and duration of marine heatwaves have increased ${ }^{55,56}$. Satellite data show a change in the South Pacific subtropical gyre associated with enhanced wind stress curl leading to recent SST warming in the Tasman Sea in all seasons ${ }^{57}$. In addition, the warm East Australian Current in the west Tasman Sea has exhibited a poleward shift and intensification in recent times ${ }^{58}$. Mid-latitude and polar teleconnection patterns are seen between the Tasman Sea and Antarctica ${ }^{59}$. A warming Tasman Sea has strengthened the westerlies between high and mid-latitudes ${ }^{60}$ (increased baroclinicity) and thus has influenced cyclone tracks over the SO. Therefore, these atmospheric circulation changes related to anomalous SST warming over the Tasman Sea would contribute to recent anomalous warm AP winters.
To investigate SST anomalies in the Tasman Sea, we focus on the difference in SST between warm and cold AP winters (Fig. 2e, Supplementary Fig. 3a). A remarkable feature of Fig. $2 \mathrm{e}$ is that the SST differences over most of the SO are quite small, with the notable exception of the significant SST differences in the Tasman Sea and to the east of New Zealand. The zonal wind speed at $300 \mathrm{hPa}$ has its strongest positive anomaly to the south of New Zealand (Fig. 2f), similar to split jet patterns with strong polar jets $^{27,61}$. However, in warm AP winters, the polar jet tends to shift poleward over the region south of Australia and New Zealand (Supplementary Figs. 3b, 4). In warm AP winters, the higher SST in the Tasman Sea strengthens the meridional SST gradient between the Tasman Sea and the SO (Supplementary Fig. 3c). Therefore, the poleward shift of the upper-level jet south of the Tasman Sea would be induced by not only La Niña and a positive SAM but also by this increase in this meridional SST gradient (Fig. 2f, Supplementary Fig. 4). The upper-level jet anomaly shifts cyclone tracks to the south over the Tasman Sea, causing the change in the atmospheric heating in the downstream regions (i.e., the Pacific sector of the SO).

Antarctic Peninsula warming without tropical heating effects. Previous investigations have shown that strengthening of the ASL can be induced by La Niña, a positive SAM, and a negative $\mathrm{IOD}^{8,9,16,22-41}$. In warm AP winters, the wave activity flux anomalies appear to originate from the subtropical Pacific to Antarctica (Fig. 3a). The tropical Pacific has a negative SST anomaly (Fig. 3b) that includes the effect of La Niña and would influence atmospheric circulation over the $\mathrm{SH}$, as reported by previous studies $8,9,16,22-39$. To investigate the atmospheric response to tropical SST anomalies in strong ENSO years, we composited the atmospheric and ocean fields for strong La Niña and El Niño winters (see "Methods" section, Fig. 3c, d, and Supplementary Figs. 5a, 6b). In the strong La Niña winters, although the wave-like anomaly patterns are similar to those in warm AP winters, a significant wave train appears to originate from the tropical Pacific region and extend to West Antarctica (Fig. 3a, c). In addition, the amplitudes and areas of tropical Pacific SST cooling are greater than those in warm AP winters (Fig. 3b, d). To remove the impact of strong ENSO in warm and cold AP winters, we determined the differences in atmospheric and ocean fields between warm and cold AP winters without strong ENSO winters (i.e., strong La Niña [1984, 1985, 1989, 1998, 2000, 2010] and strong El Niño [1987, 1991, 2002, 2009, 2015] winters) (see "Methods" section, Fig. 3e, f, and Supplementary Figs. 5b, 6c). In warm AP winters without strong La Niña, the SST cooling anomaly associated with La Niña events is not seen over the central Pacific Ocean (Fig. 3f). However, these winters exhibit a positive SST anomaly over the Tasman Sea and a significant wave-like anomaly pattern from the subtropical Pacific to Antarctica, suggesting that Tasman Sea warming anomalies contributed to these wave-like anomalies from the subtropical Pacific to West Antarctica.

We conducted similar analyses for strong SAM and strong IOD winters (see "Methods" section, Supplementary Figs. 5, 6, and 7). In strong positive SAM winters, the atmospheric circulation anomalies resemble those in warm winters over the AP (Supplementary Figs. 6d, 7a, b). The northeast AP warming, which has a significant positive correlation with the $\mathrm{SAM}^{33}$, is seen in strong positive SAM winters (Supplementary Fig. 6d). However, over the Pacific sector of the SO, the amplitudes of atmospheric circulation and wave activity flux anomalies in strong positive SAM winters are smaller than those in warm AP winters (Fig. 3a and Supplementary Fig. 7a). In addition, in warm AP winters without a strong SAM, the wave activity flux from 
Difference maps (Warm - Cold)

(a) T700 \& SLP

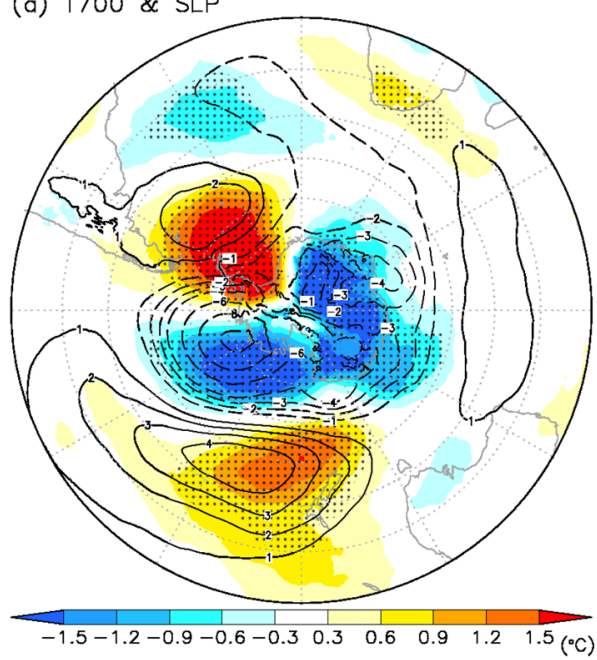

(c) Cyclone densities \& Cyclone density clim

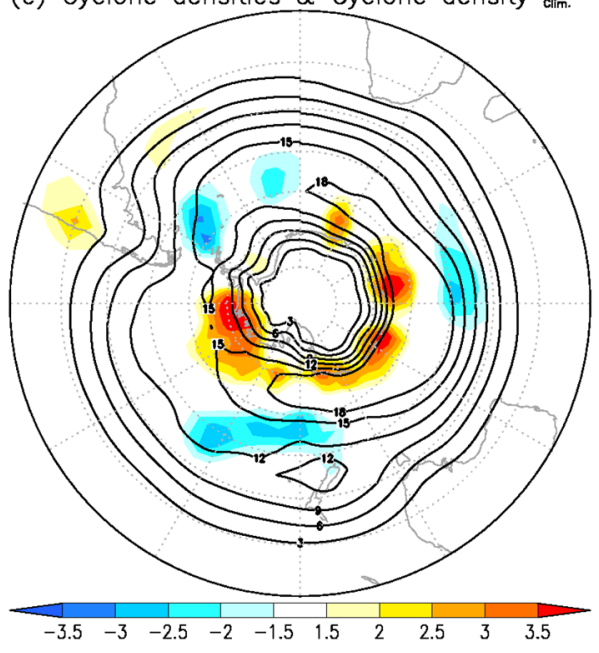

(e) SST \& SST cllm.

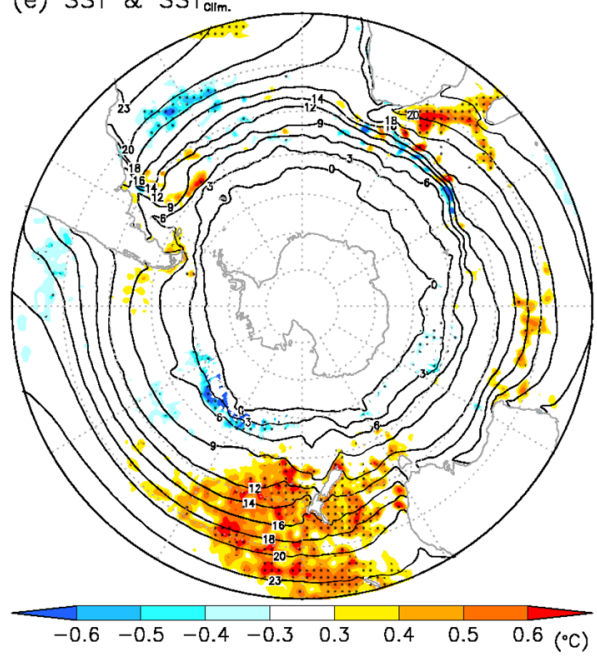

(b) Z300 \& WAF300 anomalies

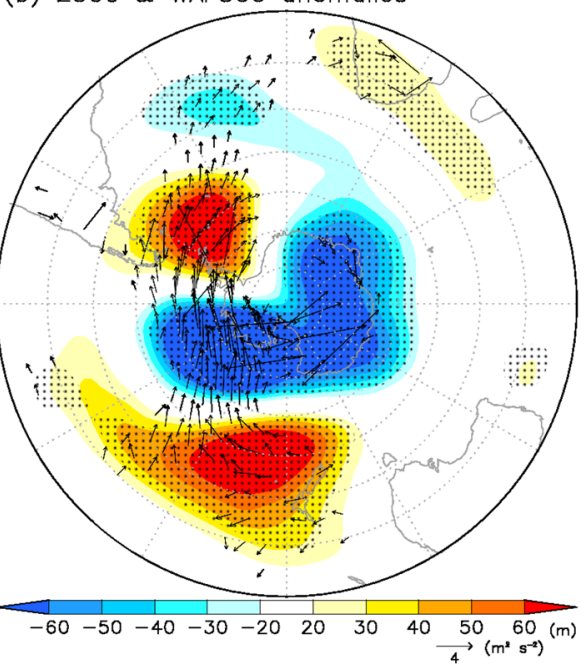

(d) Precipitation

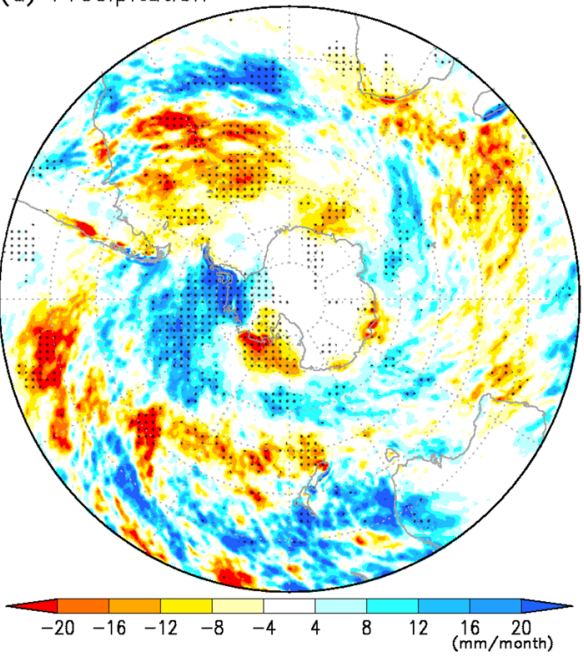

(f) UWS300 \& UWS300 ollm.

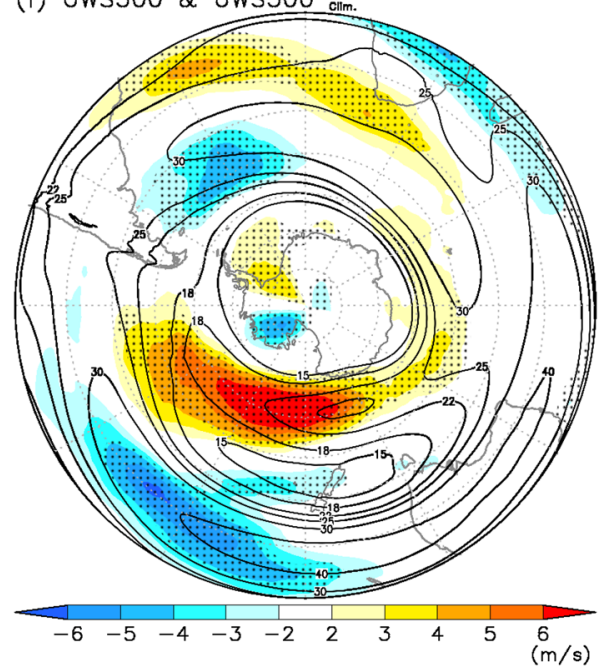

Fig. 2 Atmospheric circulation and oceanic anomalies between warm and cold AP winters over the Southern Hemisphere. Difference maps for (a) air temperature at $700 \mathrm{hPa}(\mathrm{T} 700)\left({ }^{\circ} \mathrm{C}\right.$ : shaded) and sea level pressure (SLP) (hPa: contours), (b) geopotential height at $300 \mathrm{hPa}(\mathrm{Z300})$ (m: shaded) with the horizontal component of wave-activity flux anomalies $\left(\mathrm{m}^{2} / \mathrm{s}^{2}\right.$ : vector) at $300 \mathrm{hPa}$ (WAF300) from ref. 53 , (c) cyclone density (shaded: count/S) with climatological cyclone density (count/S: contours), (d) precipitation ( $\mathrm{mm} / \mathrm{month})$, (e) sea surface temperatures (SSTs) between warm and cold winters $\left({ }^{\circ} \mathrm{C}\right.$ : shaded) with climatological SST $\left({ }^{\circ} \mathrm{C}\right.$ : contours) and (f) U-wind speed at $300 \mathrm{hPa}$ (UWS300) (m/s: shaded) with climatological UWS300 (m/s: contours) for 1979-2019 between warm and cold AP winters. Dotted areas denote significant differences exceeding the $95 \%$ confidence level. 
Z300 \& WAF300 anomalies
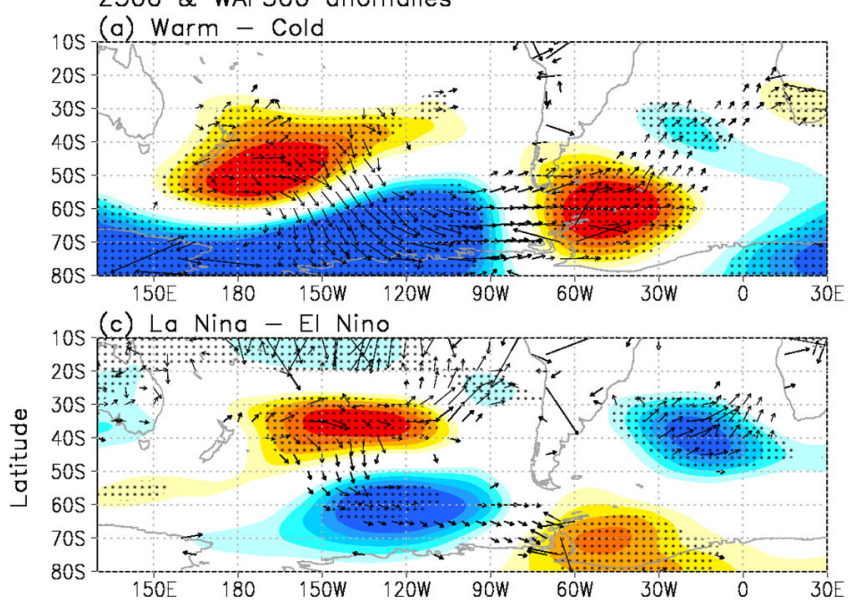

10s (e) Warm - Cold without ENSO

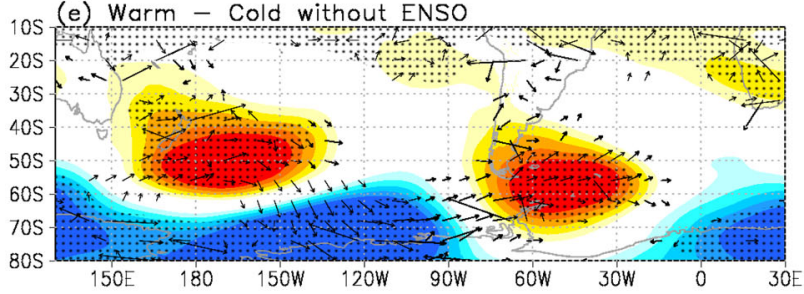

SST anomaly \& SST Clim.

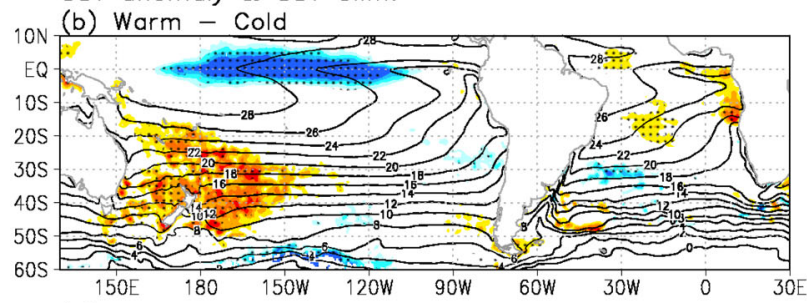

$10 \mathrm{~N}$ (d) La Nina - El Nino

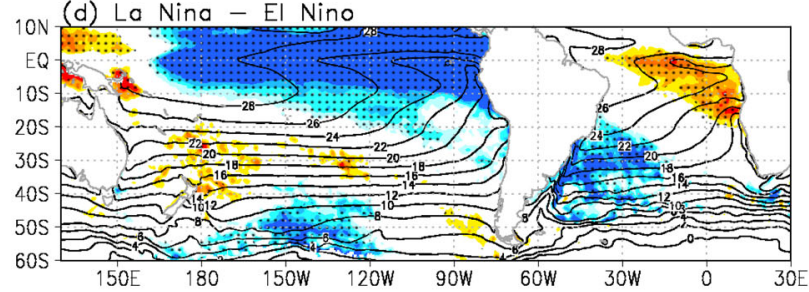

$10 \mathrm{~N}$ (f) Warm - Cold without ENSO

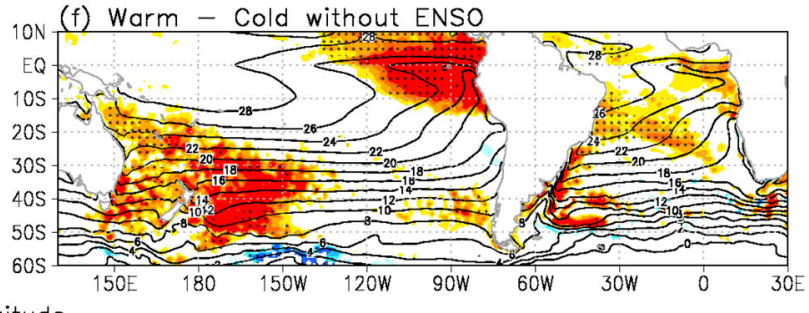

Longitude

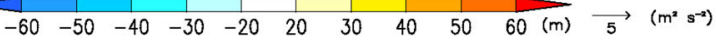

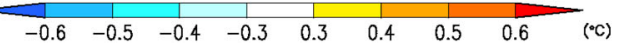

Fig. 3 Atmospheric and ocean anomalies. Difference maps for (a) geopotential height at $300 \mathrm{hPa}$ (Z300) (m: shaded) with the horizontal component of

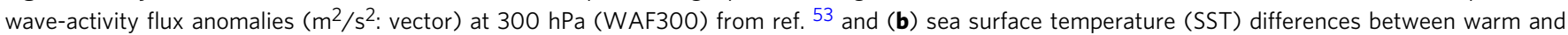
cold winters. Black contours show climate values from 1979 to 2019 for SST. Dotted areas denote significant differences exceeding the $95 \%$ confidence level. c, d, e, f Same as a, b, but for between La Niña and El Niño winters (c, d) and between warm and cold winters without strong ENSO (e, f).

south of New Zealand to West Antarctic is clearly observed as in warm AP winters (Supplementary Fig. 7c). The SSTs show a warming anomaly over the Tasman Sea and a negative anomaly over the tropical Pacific region, meaning that both SST anomalies have impacts on these atmospheric circulation anomalies. In contrast, in negative IOD winters, there are no clear wave-like anomalies over the SH (Supplementary Fig. 7e) because atmospheric anomalies over the SH linked to the IOD are found during late winter and early spring ${ }^{41}$.

In strong La Niña and positive SAM winters, the atmospheric circulation anomalies have relatively small amplitudes (Fig. 3a, c, and Supplementary Figs. 6a, b, d, and 7a). The SST anomalies in the Tasman Sea are absent in strong La Niña and positive SAM winters (Fig. 3d and Supplementary Fig. 7b). These results suggest that the SST warming over the Tasman Sea contributed to change in $\mathrm{SH}$ circulation.

\footnotetext{
Atmospheric response to the forcing over the mid-latitudes in the western Pacific. To address the atmospheric response to the SST anomalies over the Tasman Sea during warm and cold AP winters from a theoretical point of view, we conducted experiments using the AFES 62,63 (see "Methods" section). All experiments used atmospheric conditions of 1 June of each of the 41 years 1979-2019 as initial conditions and integrated for 3 winter months (June to August), meaning that each experiment has 41ensemble members. All experiment results were based on 3month averages over these 41 years. For the control experiment (CTL), climatological daily SST and sea ice cover data were used as boundary conditions. The SST anomalies over the globe between warm and cold AP winters superposed on the daily global climatology were used as forcing for a global experiment
}

(Globe) (Supplementary Fig. 8). Features of the Z300 response differences between Globe and CTL were a positive anomaly of Z300 east of Argentina and a negative anomaly over the Amundsen Sea, resulting in anomalous northerly warm advection in the lower troposphere over West Antarctica (Fig. 4a, Supplementary Fig. 9a). This anomalous pattern was similar to that observed, although the amplitudes of Z300 were smaller than those exhibited by the CFSR (Fig. 3a, Supplementary Fig. 6a).

To assess the impacts of the removal of certain tropical and Northern Hemisphere oceanic anomalies on atmospheric circulations in the $\mathrm{SH}$, we ran further experiments that were forced by SST anomalies restricted to the tropical Pacific region $\left(5^{\circ} \mathrm{S}-5^{\circ} \mathrm{S}\right.$, $170^{\circ}-260^{\circ} \mathrm{E}$ ) (ENSO experiment) and the Tasman Sea region $\left(48-32^{\circ} \mathrm{S}, 160^{\circ}-180^{\circ} \mathrm{E}\right)$ (TAS experiment) superposed on the daily global climatology (Supplementary Fig. 8 and see "Methods" section). We constructed difference maps in atmospheric circulations between the sensitivity experiments (Globe, ENSO, and TAS) and CTL.

The atmospheric response to only tropical Pacific cooling is similar to that shown in Fig. 4a (Fig. 4b, Supplementary Fig. 9b). However, in the TAS experiment, a wave-like anomaly pattern appeared from the subtropical Pacific to Antarctica in the Pacific sector, even without tropical SST forcing (Fig. 4c, Supplementary Fig. 9c). In particular, strong positive (negative) Z300 responses were observed over the east coast of Argentina (Amundsen Sea). These anomaly patterns, which induced AP warming, also originated from SST warming over the Tasman Sea. The atmospheric response to these anomalies included ridges off the southeast coast of Argentina and slightly downstream of the Drake Passage and a trough over the Amundsen Sea. The positive Z300 anomalies over the south of New Zealand and east coast of Argentina were induced by a poleward shift of cyclone tracks 


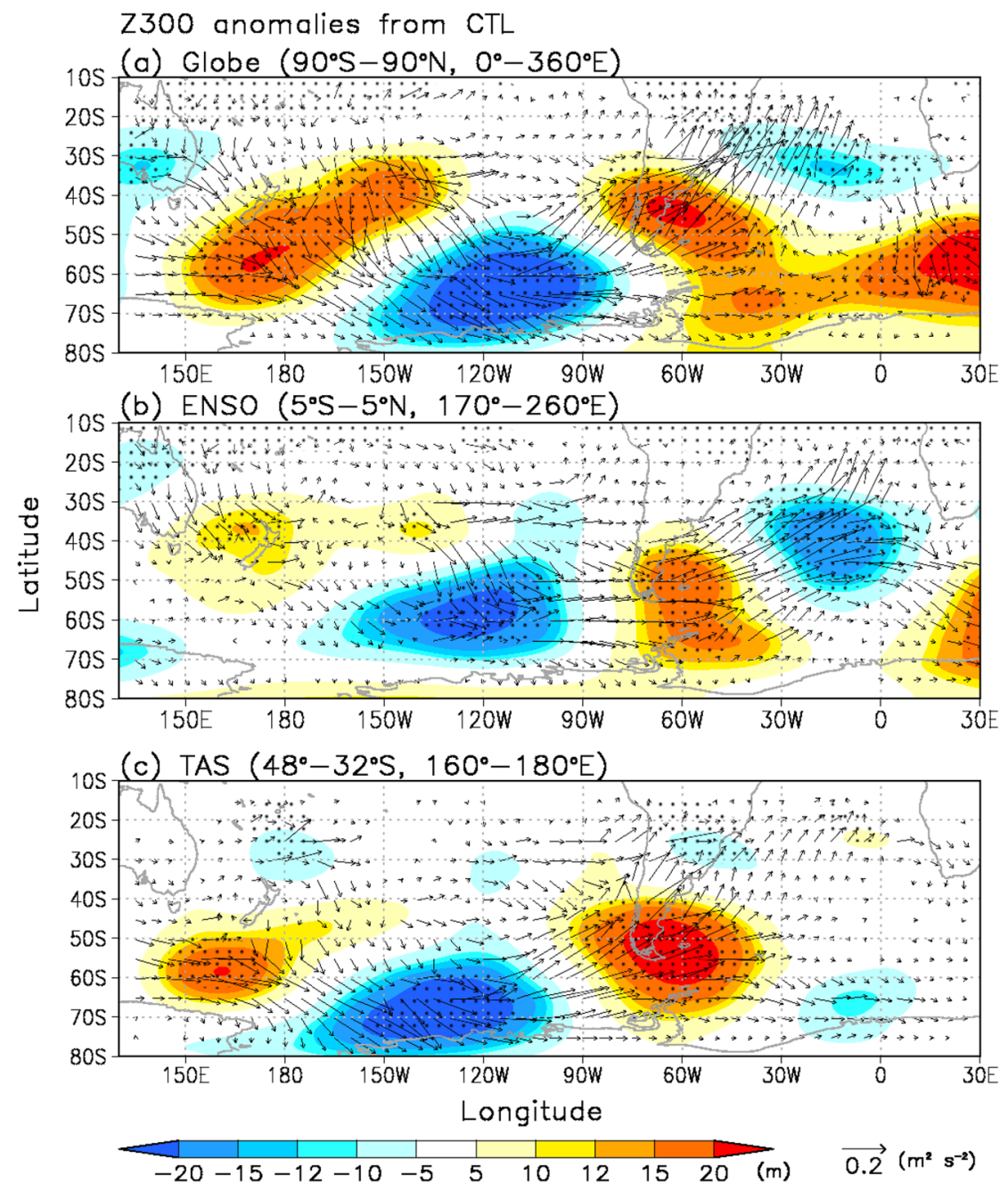

Fig. 4 Simulated atmospheric responses to SST anomalies. Geopotential height at $300 \mathrm{hPa}$ (Z300) (m: shaded) with the horizontal component of waveactivity flux anomalies ( $\mathrm{m}^{2} / \mathrm{s}^{2}$ : vector) at $300 \mathrm{hPa}$ (WAF300) from ref. 53 in (a) Globe-control experiment (CTL) difference, (b) ENSO-CTL difference and (c) TAS-CTL difference. For the CTL, climatological daily SST and sea ice cover data were used as lower boundary conditions. For each experiment (Globe, ENSO, and TAS experiment), the SST anomalies between warm and cold winters over each region (Globe: $90^{\circ} \mathrm{S}-90^{\circ} \mathrm{N}, 0-360^{\circ} \mathrm{E}, \mathrm{ENSO}: 5^{\circ} \mathrm{S}-5^{\circ} \mathrm{N}$, $\left.170-260^{\circ} \mathrm{E}, \mathrm{TAS}: 48-32^{\circ} \mathrm{S}, 160-180^{\circ} \mathrm{E}\right)$ superposed on the daily global climatology were used as forcing. Dotted areas denote significant differences exceeding the $95 \%$ confidence level.

related to the warm anomaly over the Tasman Sea, leading to northerly warm advection over the AP. To explore the statistical robustness of the results of the TAS experiment, we increase the numbers of ensemble members for CTL and TAS using initial conditions for two additional days ( 2 and 3 June in each of the 41 years), then integrated for 3 winter months as before. We diagnose a very similar response with this 123-member ensemble (Supplementary Fig. 10), indicating that our sample size of 41 is more than sufficient for establishing statistical significance.) On the basis of these results, the tropical SST cooling associated with ENSO has an important role in AP warming. However, the Tasman Sea SST anomalies alone produce warm winters in the AP.

\section{Discussion}

In summary, we have shown that warm winter episodes in the Tasman Sea influence warm temperature anomalies over key regions of West Antarctica, including the AP, through a poleward shift of South Pacific cyclone tracks. The AFES model results present new insights into remote atmospheric responses to $\mathrm{SH}$ mid-latitude perturbations and the role that these may play in influencing this sensitive region of West Antarctica. This broad concept is consistent, though in another context, with an analysis that showed that $\mathrm{SH}$ synoptic perturbations in the mid-latitudes tend to lead to variations in the Hadley Cell width ${ }^{64}$.

The dramatic increases in marine heatwaves in the Tasman Sea have a potential impact on changes in atmospheric circulation over the $\mathrm{SH}$ in other seasons. To explore this for the three other seasons, we calculated difference maps of the atmospheric circulation and SST between warm and cold AP years for which the magnitudes of the temperature anomaly values, as before, exceeded one half standard deviation at six AP stations (Supplementary Figs. 11, 12). In warm spring (September to November) and autumn (March to May) years, the atmospheric circulation anomalies that induced warming over the AP resemble those in warm winters (Fig. $3 a$ and Supplementary Fig. 12a, d). In these spring years, Tasman Sea warming and central Pacific cooling SST patterns were similar to those in warm winter years (Fig. $3 \mathrm{~b}$ and Supplementary Fig. 12c). In contrast, in warm autumn years, there was significant warming over the Tasman Sea without tropical cooling (Supplementary Fig. 12f). On the basis of these results, although the $\mathrm{SH}$ atmospheric circulation anomalies were related to both SST anomalies in spring 
years, the AP warming was induced by SST warming over the Tasman Sea even without anomalous tropical SST cooling in warm autumn years. In warm AP summers (December to February), there were small differences in surface temperature at the six AP stations between warm and cold summers (Supplementary Fig. 11c). Therefore, the atmospheric responses to the tropical Pacific SST cooling were not clearly observed over the SH as reported in previous studies (Supplementary Fig. 12g-i). Our study has particular relevance because the Tasman Sea has been identified as one that impacts the AP climate, except for in summer.

\begin{abstract}
Methods
Observation data. The Antarctic Climate Data, which includes temperature, surface pressure, and winds observed at manned and automatic weather stations, are available from the SCAR READER project (https://legacy.bas.ac.uk/met/ READER) ${ }^{65}$. In this study, we selected six stations (Bellingshausen, O'Higgins, Esperanza, Marambio, Vernadsky, and Rothera) on the AP. Monthly averaged surface temperature data from these six AP stations were used in Fig. 1a. From this time series, we selected anomalous warm and cold winters (June to August) for which the magnitudes of the temperature anomaly values exceeded one half of a standard deviation (warm winters: 1983-1985, 1989, 1998, 2000, 2004, 2008, 2010, 2014, 2016, and 2018-2019; cold winters: 1980, 1986-1987, 1991-1992, 1994-1995, 2002, 2007, 2009, 2011 and 2015). In addition, for the other three seasons (spring [September to November], summer [December to February], and autumn [March and May]), we similarly selected warm and cold years (Supplementary Fig. 11).
\end{abstract}

Reanalysis data. We used 6-h data of the Climate Forecast System Reanalysis ${ }^{49}$ (CFSR) from January 1979 to March 2011 and CFS Version $2^{50}$ from April 2011. The CFSR and CFS data on a $0.5^{\circ}$ horizontal grid is provided by the National Centers for Environmental Prediction (NCEP). We used meteorological (SLP, air temperature, wind speed, geopotential height, and precipitation) and oceanographic (sea ice concentration, sea surface temperature, and ice drifting speed) parameters. The wave activity flux representing stationary Rossby wave propagation was based on ref. ${ }^{53}$. In this study, the significance test was a standard twotailed $t$-test with degrees of freedom based on the number of years in the figures and supplementary figures.

It is important to establish that our results do not depend on this specific choice of reanalysis set. Accordingly, we also made use of the European Centre for Medium-Range Weather Forecasts (ECMWF) ERA5 compilation ${ }^{66}$ with a horizontal resolution of $0.5^{\circ} \times 0.5^{\circ}$. We constructed difference maps of T700, SLP, Z300, and wave activity fluxes at $300 \mathrm{hPa}$ (WAF300) with the ERA5 data in the same form as in Fig. 2 (Supplementary Fig. 13). To reduce uncertainty in reanalysis data, the means of the 10 ensemble members of ERA5 were used. The plots differed little from those constructed with the NCEP product.

Cyclone tracking data. We used cyclone tracking data derived from an algorithm developed at the University of Melbourn ${ }^{67}$. This algorithm identifies the cyclone positions at 6-h intervals based on the Laplacian of pressure at each grid. Cyclones lasting less than $24 \mathrm{~h}$ were removed from the analysis. To investigate cyclone density, we calculated the densities of cyclones in a circular grid ${ }^{68}$ with circular cells of a $5^{\circ}$ latitude radius (equivalent to approximately $308,025 \mathrm{~km}^{2}$ ) (units: count/S) for each year.

NINO3.4 index. Monthly averaged SST anomalies were calculated for the NINO3.4 region $\left(5^{\circ} \mathrm{S}-5^{\circ} \mathrm{N}, 190^{\circ}-240^{\circ} \mathrm{E}\right)$. For our June to August period (Supplementary Fig. 5a), analogous to above, we identified strong La Niña and El Niño winters for which the NINO3.4 index values exceeded one half standard deviation (strong La Niña winters: 1981, 1984-1985, 1988-1989, 1995-1996, 1998-2000, and 2010; strong El Niño winters: 1982, 1987, 1991, 1997, 2002, 2004, 2009, 2012, and 2015). Using the CFSR data, we constructed difference maps of T700 with SLP, Z300 with WAF300, and SST with climatology SST values between La Niña and El Niño winters, as shown in Fig. 3a, b and Supplementary Fig. 6a (Fig. 3c, d and Supplementary Fig. 6b).

Southern Annular Mode (SAM) index. Observation-based Southern Hemisphere Annular Mode Index data ${ }^{69}$ were used as the SAM index (available from https:// legacy.bas.ac.uk/met/gima/sam.html). From this anomaly time series for June to August (Supplementary Fig. $5 \mathrm{c}$ ), we extracted strong positive and negative SAM winters, defined as those for which the magnitude of the SAM index values exceeded one half standard deviation (strong SAM+ winters: 1979, 1982, 1989, 1993, 1997, 1998, 2004, 2008, 2010, 2012, and 2015-2016; strong SAM- winters: 1981, 1984, 1988, 1990-1992, 1994-1996, 2000, 2007, 2009, 2011, 2013, and 2018-2019). Using the CFSR data, we constructed difference maps of T700 with
SLP, Z300 with WAF300, and SST with climatology SST values between strong SAM + and SAM - winters, as shown in Fig. 3a, b and Supplementary Fig. 6a (Supplementary Figs. 6d and 7a, b).

Indian Ocean dipole index. The Indian Ocean Dipole (IOD) index ${ }^{70}$ is defined as the SST anomaly difference between the tropical western Indian Ocean $\left(10^{\circ} \mathrm{S}-10^{\circ}\right.$ $\left.\mathrm{N}, 50^{\circ}-70^{\circ} \mathrm{E}\right)$ and tropical southeast Indian Ocean $\left(10^{\circ} \mathrm{S}-0^{\circ}, 90^{\circ}-110^{\circ} \mathrm{E}\right.$ ) (Supplementary Fig. 5e). From this anomaly time series for June to August, we selected strong positive and negative IOD winters for which the IOD index values exceeded one standard deviation (strong IOD+ winters: 1982-1983, 1994, 1997, 2003, 2007-08, 2012, 2015, and 2017-2019; strong IOD- winters: 1980-1981, 1984-1986, 1989, 1992, 1995-1996, 1998, 2001-2002, 2004-2005, 2009, 2013-2014, and 2016). Using the CFSR data, we constructed difference maps of T700 with SLP, Z300 with WAF300, and SST with climatology SST values between strong IOD - and IOD + winters, as shown in Fig. 3a, b and Supplementary Fig. 6a (Supplementary Figs. 6f, 7e, f).

Removal of the impacts of ENSO and SAM. To remove the impact of ENSO in warm and cold winters, we composited the atmospheric and ocean fields for warm and cold AP winters without strong ENSO winters (e.g., strong La Niña [1984-1985, 1989, 1998, 2000, and 2010] and strong El Niño [1987, 1991, 2002, 2009, and 2015] winters) (Supplementary Fig. 5b). We then formed the difference maps of these (Fig. 3e, f, and Supplementary Fig. 6c). In a similar fashion, we removed the impact of the SAM on warm and cold AP winters by assembling different maps of the atmosphere and ocean between warm and cold AP winters without a strong SAM (e.g., SAM+ [1989, 1998, 2004, 2008, 2010, and 2016] and SAM - (1991-1992, 1994-1995, 2007, 2009, 2011) winters) (Supplementary Figs. 5d, 6e, 7c, d).

The atmospheric general circulation model For Earth Simulator (AFES). To conduct sensitivity experiments, we used the Atmospheric general circulation model For Earth Simulator (AFES) ${ }^{62,63}$. The AFES with a horizontal resolution of T119 (triangular spectral truncation with a truncation wavenumber of $119, \sim 1^{\circ} \times$ $\left.1^{\circ}\right)$ and 48 vertical levels reproduced the geopotential height and temperature structures of large-scale circulation in the troposphere and lower stratosphere, as well as other reanalysis products ${ }^{71-73}$. In this study, we ran all experiments initialized with atmospheric conditions of 1 June of each year (1979-2019) and integrated for 3 winter months (June to August). For the control experiment (CTL), climatological daily SST and sea ice cover data were used as lower boundary conditions. Supplementary Fig. 8 shows the difference in SSTs between warm and cold winters with climatological SST and sea ice cover in the winter months. To calculate the atmospheric response to SST anomalies over the entire globe $\left(90^{\circ}\right.$ $\left.\mathrm{S}-90^{\circ} \mathrm{N}, 0-360^{\circ} \mathrm{E}\right)$, the tropical region $\left(5^{\circ} \mathrm{S}-5^{\circ} \mathrm{N}, 170-260^{\circ} \mathrm{E}\right.$; orange line in Supplementary Fig. 8$)$ and the Tasman Sea area $\left(48-32^{\circ} \mathrm{S}, 160-180^{\circ} \mathrm{E}\right.$; purple line in Supplementary Fig. 8), the SST anomalies between warm and cold winters over each region superposed on the daily global climatology were used as forcing for each experiment. For all experiments, results were based on 3-month averages from 1979 to 2019. The ERA5 data were used as atmospheric initial conditions and boundary conditions for the AFES.

\section{Data availability}

The surface temperature datasets were obtained from the SCAR READER project (https://legacy.bas.ac.uk/met/READER). We used the observation-based Southern Hemisphere Annular Mode Index (https://legacy.bas.ac.uk/met/gjma/sam.html). To composite atmospheric and oceanic maps, we used the CFSR (https://rda.ucar.edu/) and ERA5 (available from https://www.ecmwfint/) reanalyses provided by the NCEP and ECMWF. AFES experiment data are available from the corresponding author on request.

\section{Code availability}

All codes used to analyze and plot the data are available from the corresponding author on request.

Received: 2 October 2019; Accepted: 8 February 2021; Published online: 08 March 2021

\section{References}

1. Turner, J., Maksym, T., Phillips, T., Marshall, G. J. \& Meredith, M. P. The impacts of changes in sea ice advance on the large winter warming on the western Antarctic Peninsula. Int. J. Climatol. 33, 852-861 (2013).

2. Bromwich, D. H. et al. Central West Antarctica among the most rapidly warming regions on Earth. Nat. Geosci. 6, 139-145 (2013).

3. Gonzalez, S. \& Fortuny, D. How robust are the temperature trends on the Antarctic Peninsula? Antarct. Sci. 30, 322-328 (2018). 
4. Turner, J., Lachlan-Cope, T. A., Colwell, S., Marshall, G. J. \& Connolley, W. M. Significant warming of the Antarctic winter troposphere. Science 311, 1914-1917 (2006).

5. Screen, J. A. \& Simmonds, I. Half-century air temperature change above Antarctica: observed trends and spatial reconstructions. J. Geophys. Res. 117, D16108 (2012)

6. Steig, E. J. et al. Warming of the Antarctic ice-sheet surface since the 1957 International Geophysical Year. Nature 457, 459-462 (2009).

7. O’Donnell, R., Lewis, N., McIntyre, S. \& Condon, J. Improved methods for PCA-based reconstructions: case study using the Steig et al. (2009) Antarctic temperature reconstruction. J. Clim. 24, 2099-2115 (2010).

8. Ding, Q., Steig, E. J., Battisti, D. S. \& Kuttel, M. Winter warming in West Antarctica caused by central tropical Pacific warming. Nat. Geosci. 4, 398-403 (2011).

9. Ding, Q. \& Steig, E. J. Temperature change on the Antarctic Peninsula linked to the tropical Pacific. J. Clim. 26, 7570-7585 (2013).

10. Turner, J. et al. Absence of 21 st century warming on Antarctic Peninsula consistent with natural variability. Nature 535, 411-415 (2016)

11. Nicolas, J. P. \& Bromwich, D. H. New reconstruction of Antarctic near-surface temperatures: multidecadal trends and reliability of global reanalyses. J. Clim. 27, 8070-8093 (2014).

12. Simmonds, I., Keay, K. \& Lim, E. P. Synoptic activity in the seas around Antarctica. Mon. Weather Rev. 131, 272-288 (2003).

13. Simmonds, I. \& Keay, K. Mean Southern Hemisphere extratropical cyclone behavior in the 40-year NCEP-NCAR reanalysis. J. Clim. 13, 873-885 (2000).

14. Fogt, R. L., Wovrosh, A. J., Langen, R. A. \& Simmonds, I. The characteristic variability and connection to the underlying synoptic activity of the Amundsen-Bellingshausen Seas Low. J. Geophys. Res. 117, D07111 (2012).

15. Hosking, J. S., Orr, A., Marshall, G. J., Turner, J. \& Phillips, T. The influence of the Amundsen-Bellingshausen Seas low on the climate of West Antarctica and its representation in coupled climate model simulations. J. Clim. 26, 6633-6648 (2013).

16. Clem, K. R., Renwick, J. A. \& McGregor, J. Large-scale forcing of the Amundsen Sea low and its influence on sea ice and West Antarctic temperature. J. Clim. 30, 8405-8424 (2017).

17. Thompson, D. W. J. \& Solomon, S. Interpretation of recent Southern Hemisphere climate change. Science 296, 895-899 (2002).

18. Simmonds, I. Modes of atmospheric variability over the Southern Ocean. J. Geophys. Res. 108, 8078 (2003).

19. Thompson, D. W. J. et al. Signatures of the Antarctic ozone hole in Southern Hemisphere surface climate change. Nat. Geosci. 4, 741-749 (2011).

20. Bader, J., Flügge, M., Kvamstø, N. G., Mesquita, M. D. S. \& Voigt, A. Atmospheric winter response to a projected future Antarctic sea-ice reduction: a dynamical analysis. Clim. Dyn. 40, 2707-2718 (2013).

21. Simmonds, I. \& King, J. C. Global and hemispheric climate variations affecting the Southern Ocean. Antar. Sci. 16, 401-413 (2004).

22. Ciasto, L. M., Simpkins, G. R. \& England, M. H. Teleconnections between tropical Pacific SST anomalies and extratropical Southern Hemisphere climate. J. Clim. 28, 56-65 (2015).

23. Li, X., Holland, D. M., Gerber, E. P. \& Yoo, C. Rossby waves mediate impacts of tropical oceans on West Antarctic atmospheric circulation in austral winter. J. Clim. 28, 8151-8164 (2015).

24. Irving, D. \& Simmonds, I. A new method for identifying the Pacific-South American pattern and its influence on regional climate variability. J. Clim. 29, 6109-6125 (2016).

25. Pezza, A. B., Rashid, H. A. \& Simmonds, I. Climate links and recent extremes in Antarctic sea ice, high-latitude cyclones, Southern Annular Mode and ENSO. Clim. Dyn. 38, 57-73 (2012).

26. Stammerjohn, S. E., Martinson, D. G., Smith, R. C., Yuan, X. \& Rind, D. Trends in Antarctic annual sea ice retreat and advance and their relation to ENSO and southern annular mode variability. J. Geophys. Res. 113, C03S90 (2008).

27. Marshal, G. J. \& King, J. C. Southern Hemisphere circulation anomalies associated with extreme Antarctic Peninsula winter temperature. Geophys. Res. Lett. 25, 2437-2440 (1998).

28. Ding, Q., Steig, E. J., Battisti, D. S. \& Wallace, J. M. Influence of the Tropics on the Southern Annular Mode. J. Clim. 25, 6330-6348 (2012).

29. Fogt, R. L. \& Bromwich, D. H. Decadal variability of the ENSO teleconnection to the high-latitude south Pacific governed by coupling with the Southern Annular Mode. J. Clim. 19, 979-997 (2005).

30. Clem, K. R. \& Fogt, R. L. South Pacific circulation changes and their connection to the tropics and regional Antarctic warming in austral spring, 1979-2012. J. Geophys. Res. Atmos. 120, 2773-2792 (2015).

31. Marshall, G. J. \& Thompson, D. J. W. The signatures of large-scale patterns of atmospheric variability in Antarctic surface temperature. J. Geophys. Res. Atmos. 121, 3276-3289 (2016).
32. Clem, K. R. \& Fogt, R. L. Varying roles of ENSO and SAM on the Antarctic Peninsula climate in austral spring. J. Geophys. Res. Atmos. 118, 11481-11492 (2013).

33. Clem, K. R., Renwick, J. A., McGregor, J. \& Fogt, R. L. The relative influence of ENSO and SAM on Antarctica Peninsula climate. J. Geophys. Res. Atmos. 121, 9324-9341 (2016).

34. L'Heureux, M. L. \& Thompson, D. W. J. Observed relationships between the El Nino-Southern Oscillation and the extratropical zonal-mean circulation. J. Clim. 19, 276-287 (2005).

35. Li, X., Holland, D. M., Gerber, E. P. \& Yoo, C. Impacts of the north and tropical Atlantic Ocean on the Antarctic Peninsula and sea ice. Nature 505, 538-542 (2014).

36. Irving, D. \& Simmonds, I. A novel approach to diagnosing Southern Hemisphere planetary wave activity and its influence on regional climate variability. J. Clim. 28, 9041-9057 (2015).

37. Yiu, Y. Y. S. \& Maycock, A. C. On the seasonality of the El Niño teleconnection to the Amundsen Sea region. J. Clim. 32, 4829-4845 (2019).

38. Schneider, D. P., Deser, C. \& Okumura, Y. An assessment and interpretation of the observed warming of West Antarctica in the austral spring. Clim. Dyn. 38, 323-347 (2011).

39. Fogt, R. L., Bromwich, D. H. \& Hines, K. M. Understanding the SAM influence on the South Pacific ENSO teleconnection. Clim. Dyn. 36, 1555-1576 (2010)

40. Liu, N., Jia, Z., Chen, H., Hua, F. \& Li, Y. Southern high latitude climate anomalies associated with the Indian Ocean dipole mode. Chin. J. Ocean. Limnol. 24, 125-128 (2005)

41. Nuncio, M. \& Yuan, X. The influence of the Indian Ocean dipole on Antarctic sea ice. J. Clim. 28, 2682-2690 (2015).

42. Deser, C., Simpson, I. R., McKinnon, K. A. \& Phillips, A. S. The Northern Hemisphere extratropical atmospheric circulation response to ENSO: How well do we know it and how do we evaluate models accordingly? J. Clim. 30 5059-5082 (2017).

43. Screen, J. A. \& Simmonds, I. Exploring links between Arctic amplification and mid-latitude weather. Geophys. Res. Lett. 40, 959-964 (2013).

44. Kosaka, Y. \& Xie, S.-P. Recent global-warming hiatus tied to equatorial Pacific surface cooling. Nature 501, 403-407 (2013).

45. Sato, K., Inoue, J. \& Watanabe, M. Influence of the Gulf Stream on the Barents Sea ice retreat and Eurasian coldness during early winter. Environ. Res. Lett. 9, 084009 (2014).

46. Simmonds, I. \& Govekar, P. D. What are the physical links between Arctic sea ice loss and Eurasian winter climate? Environ. Res. Lett. 9, 101003 (2014).

47. Nakanowatari, T., Inoue, J., Sato, K. \& Kikuchi, T. Summertime atmosphereocean preconditionings for the Bering Sea ice retreat and the following severe winters in North America. Environ. Res. Lett. 10, 094023 (2015).

48. Tokinaga, H., Xie, S.-P. \& Mukougawa, H. Early 20th-century Arctic warming intensified by Pacific and Atlantic multidecadal variability. PNAS 114, 6227-6232 (2017)

49. Saha, S. et al. The NCEP climate forecast system reanalysis. Bull. Am. Meteorol. Soc. 91, 2185-2208 (2010).

50. Saha, S. et al. The NCEP climate forecast system version 2. J. Clim. 27, 2185-2208 (2014).

51. Bracegirdle, T. J. \& Marshall, G. J. The reliability of Antarctic tropospheric pressure and temperature in the Latest Global Reanalysis. J. Clim. 25, 7138-7146 (2012)

52. Raphael, M. N. A zonal wave 3 index for the Southern Hemisphere. Geophys. Res. Lett. 31, L23212 (2004)

53. Takaya, K. \& Nakamura, H. A formulation of a phase-independent waveactivity flux for stationary and migratory quasigeostrophic eddies on a zonally varying basic flow. J. Atmos. Sci. 58, 608-627 (2001).

54. Oliver, E. C. J. et al. The unprecedented 2015/16 Tasman Sea marine heatwave. Nat. Commun. 8, 16101 (2017).

55. Oliver, E. C. J., Wotherspoon, S. J., Chamberlain, M. A. \& Holbrook, N. J. Projected Tasman Sea extremes in sea surface temperature through the twenty-first century. J. Clim. 27, 1980-1998 (2014).

56. Oliver, E. C. J. et al. Longer and more frequent marine heatwaves over the past century. Nat. Commun. 9, 03732 (2018).

57. Shears, N. T. \& Bowen, M. M. Half a century of coastal temperature records reveal complex warming trends in western boundary currents. Sci. Rep. 7, 14527 (2017)

58. Wu, L. et al. Enhanced warming over the global subtropical western boundary currents. Nat. Clim. Change 2, 161-166 (2012).

59. Liess, S. et al. Different modes of variability over the Tasman Sea: implications for regional climate. J. Clim. 27, 8466-8486 (2014).

60. Duran, E. R., England, M. H. \& Spence, P. Surface ocean warming around Australia driven by interannual variability and long-term trends in Southern Hemisphere westerlies. Geophys. Res. Lett. 47, e2019GL086605 (2020).

61. Bals-Elsholz, T. M. et al. The wintertime Southern Hemisphere split jet: structure, variability, and evolution. J. Clim. 14, 4191-4215 (2001). 
62. Ohfuchi, W. et al. 10-km mesh meso-scale resolving simulations of the global atmosphere on the Earth Simulator-Preliminary outcomes of AFES (AGCM for the Earth Simulator). J. Earth Sim. 1, 8-34 (2004).

63. Enomoto, T., Kuwano-Yoshida, A., Komori, N., \& Ohfuchi, W. Description of AFES 2: improvements for high-resolution and coupled simulations. In High Resolution Numerical Modelling of the Atmosphere and Ocean (eds. Hamilton, K. \& Ohfuchi, W.), 77-97, (Springer, 2008).

64. Rudeva, I., Simmonds, I., Crock, D. \& Boschat, G. Midlatitude fronts and variability in the Southern Hemisphere tropical width. J. Clim. 32, 8243-8260 (2019).

65. Turner, J. et al. The SCAR READER project: toward a high-quality database of mean Antarctic meteorological observations. J. Clim. 17, 2890-2898 (2004).

66. Hersbach, H. et al. The ERA5 global reanalysis. Q. J. R. Meteorol. Soc. 146, 1999-2049 (2020).

67. Simmonds, I. \& Murray, R. J. Southern extratropical cyclone behaviour in ECMWF analyses during the FROST special observing periods. Weather Forecast 14, 878-891 (1999).

68. Rudeva, I., Gulev, S. K., Simmonds, I. \& Tilinina, N. The sensitivity of characteristics of cyclone activity to identification procedures in tracking algorithms. Tellus A 66, 24961 (2014).

69. Marshall, G. J. Trends in the Southern Annular Mode from observations and reanalyses. J. Clim. 16, 4134-4143 (2003).

70. Saja, N. H., Goswami, B. N., Vinayachandran, P. N. \& Yamagata, T. A dipole mode in the tropical Indian Ocean. Nature 401, 360-363 (1999).

71. Inoue, J., Enomoto, T. \& Hori, M. E. The impact of radiosonde data over the ice-free Arctic Ocean on the atmospheric circulation in the Northern Hemisphere. Geophys. Res. Lett. 40, 864-869 (2013).

72. Yamazaki, A., Inoue, J., Dethloff, K., Maturilli, M. \& König-Langlo, G. Impact of radiosonde observations on forecasting summertime Arctic cyclone formation. J. Geophys. Res. Atmos. 120, 3249-3273 (2015).

73. Sato, K. et al. Improved forecasts of winter weather extremes over midlatitudes with extra Arctic observations. J. Geophys. Res. Oceans 122, 775-787 (2017).

\section{Acknowledgements}

This work was supported by a JSPS Overseas Research Fellowship, JSPS KAKENHI (20H04963, 19K14802, 18H05053). Parts of this research were made possible by funding from the Australian Research Council (Grant DP16010997). The AFES integration was performed on the Earth Simulator with the support of JAMSTEC. We thank Sara J. Mason for correcting a draft of this manuscript.

\section{Author contributions}

K.S. and J.I. designed the research. K.S., J.I., and I.S. wrote the paper. I.R. made cyclone track data sets. K.S. conducted the experiments using the AFES. All authors commented on the manuscript.

\section{Competing interests}

The authors declare no competing interests.

\section{Additional information}

Supplementary information The online version contains supplementary material available at https://doi.org/10.1038/s41467-021-21773-5.

Correspondence and requests for materials should be addressed to K.S.

Peer review information Nature Communications thanks Kyle Clem and the other, anonymous, reviewer(s) for their contribution to the peer review of this work. Peer reviewer reports are available.

Reprints and permission information is available at http://www.nature.com/reprints

Publisher's note Springer Nature remains neutral with regard to jurisdictional claims in published maps and institutional affiliations.

\section{(c) (i)}

Open Access This article is licensed under a Creative Commons Attribution 4.0 International License, which permits use, sharing, adaptation, distribution and reproduction in any medium or format, as long as you give appropriate credit to the original author(s) and the source, provide a link to the Creative Commons license, and indicate if changes were made. The images or other third party material in this article are included in the article's Creative Commons license, unless indicated otherwise in a credit line to the material. If material is not included in the article's Creative Commons license and your intended use is not permitted by statutory regulation or exceeds the permitted use, you will need to obtain permission directly from the copyright holder. To view a copy of this license, visit http://creativecommons.org/ licenses/by/4.0/.

(C) The Author(s) 2021 